\title{
Effects of a decomposing drift algal mat on sediment pore water nutrient concentrations in a Florida seagrass bed
}

\author{
Carl F. Zimmermann and John R. Montgomery
}

Harbor Branch Foundation, Inc. R. R. 1, Box 196, Ft. Pierce, Florida 33450, USA

\begin{abstract}
A rapid increase in sediment pore water nutrient concentrations, from 300 to $900 \mu \mathrm{M}$ ammonium- $\mathrm{N}$ and 20 to $200 \mu \mathrm{M}$ dissolved reactive phosphate- $\mathrm{P}$, followed by an equally rapid decline to initial concentrations, was noted between May and July 1978 in the Indian River lagoon, Florida, USA. These events coincided with the occurrence and physical state of a drift algal mat composed of Microcoleus lyngbyaceus and various seagrasses. It is suggested that the sinking and decomposition of the algal mat over the sample site reversed the nutrient concentration gradient and caused a buildup of nutrients in the sediment.
\end{abstract}

Estuarine ecosystems rely on sediment pore water as a source of nutrients either as a result of molecular diffusion (Berner, 1974; Rosenfeld, 1979) or through the biological processes of marine organisms (Aller, 1978; Aller and Yingst, 1978). Seagrasses are also important in cycling nutrients from the sediment to the overlying water (McRoy and Barsdate, 1970; McRoy et al., 1972; Short, 1983). In certain instances, situations arise where the naturally occurring processes of sediment pore water supplying nutrients to the overlying water are altered.

This report describes the effect of drift algae on sediment pore water nutrient concentrations in a Halodule wrightii Asherson seagrass bed in the Indian River lagoon, Florida, USA. The occurrence of drift algal communities in the Indian River, Florida was documented by Benz et al. (1979), who found Microcoleus lyngbyaceus to grow abundantly during the summer months as a mat over the bottom and on seagrasses. We hypothesize that these drift assemblages influence the nutrient dynamics of the area.

A large drift algal mat composed primarily of the blue green alga Microcoleus lyngbyaceus Kützing and uprooted seagrasses (Halodule wrightii, Thalassia testudinum Banks EX König and Syringodium filiforme Kützing) drifted onto and out of the study area during a three month period. During May, 1978 we observed a large algal mat moving in a west-southwesterly direction. By the end of May and into early June, the mat and its associated uprooted seagrasses had sunk and started to decompose; encompassing an area approximately $25 \times 200 \mathrm{~m}$. Weekly observations indicated that from 12 to 26 June, the area bottom was still covered with the decomposing algal mat and that a strong hydrogen sulfide odor was present. In early July, the algal mat covered the shoreline and only patches $\left(\sim \mathrm{m}^{2}\right)$ of the decomposing mat were present on the bottom. During July, the mat continued to dissipate at the study site and by early August the study area showed no signs of the algal mat. Field notes describing the condition of the algal mat, coupled with chemical data from surface and pore waters, are presented to illustrate the dynamic nutrient interactions of a drift algal mat and sediments.

The Indian River is a narrow estuarine lagoon system extending approximately $182 \mathrm{~km}$ along the east coast of Florida. The mean water depth is approximately $1.5 \mathrm{~m}$ and tides are semidiurnal with a tidal amplitude of approximately $0.5 \mathrm{~m}$. Our sample site was located in a shallow area predominated by the seagrass Halodule wrightii and has been the site of other investigations (Montgomery et al., 1983). The study site was located on the west side of the lagoon and was protected from northerly and westerly winds.

The data presented in this note was part of a study which investigated the weekly changes in pore water nutrient concentrations spanning a one year time period. A control site (an area devoid of seagrass) was established approximately $100 \mathrm{~m}$ from the seagrass site. Unfortunately, it was also influenced by the algal mat.

Pore water samples were collected weekly from the sediments of a Halodule wrightlii seagrass bed at approximately the same time of day from 8 May to 
17 July and 7 August 1978, using in situ porous Teflon samplers (Zimmermann et al., 1978). Replicate samplers were placed at $10,20,30$ and $40 \mathrm{~cm}$ in a double diamond pattern with the 2 middle samplers $0.5 \mathrm{~m}$ apart; encompassing an area $1.5 \times 3.0 \mathrm{~m}$. Care was taken not to place two samplers next to each other at the same depth. These samplers were allowed to equilibrate in the sediment for $2 \mathrm{wk}$ and remained in place for the duration of the experiment. At the 'control' site, samples were collected at the surface, 2 and $20 \mathrm{~cm}$ depths. The actual location with respect to depth that samples were collected was 8 to 10,18 to 20,28 to 30 and 38 to $40 \mathrm{~cm}$. Samples from the surface $(50 \mathrm{~cm}$ depth in the water column), $2 \mathrm{~cm}$ sediment depth as well as the 10 to $40 \mathrm{~cm}$ depths were analyzed for dissolved reactive phosphate (DRP), ammonium $\left(\mathrm{NH}_{4}{ }^{-}\right.$ $\mathrm{N})$ and platinum electrode potentials (PEP). Only 1 sample $\mathrm{wk}^{-1}$ was collected at the $2 \mathrm{~cm}$ depth. All chemical samples were analyzed the same day as collection. DRP and $\mathrm{NH}_{4}-\mathrm{N}$ were determined on an AutoAnalyzer II system (Zimmermann et al., 1977) on samples which were filtered through acid-washed GFC filters. Analyses were performed in an inert atmosphere (Montgomery et al., 1979) and pore water samples were diluted with argon-purged artificial seawater to maintain maximum sensitivity on the AutoAnalyzer II. Sample dilution also helped in eliminating any possible sulfide interference with the phosphate determination (DeJong and Villerius, 1980). PEP of the samples were measured under inert conditions with an Orion digital scale pH meter equipped with an Orion combination redox specific ion electrode. Surface oxygen values were measured with a YSI Modell 51-A oxygen meter and sediment temperatures measured with in situ probes combined with a YSI Model 43 telethermometer.

Increases up to 3 -fold for $\mathrm{NH}_{4}-\mathrm{N}$ and 10 -fold for DRP in pore water nutrient concentrations at a depth of $10 \mathrm{~cm}$ were observed from 16 May to 19 June 1978 with a decrease from 19 June to 7 August 1978 (Fig. 1). Replicate sampler data for samples collected at $10 \mathrm{~cm}$ depth indicated coefficients of variation (CV) ranging from 10 to $40 \%$ for $\mathrm{NH}_{4}-\mathrm{N}$ and from 5 to $50 \%$ for DRP. Montgomery et al. (1979) found similar coefficients of variation in a similar area. The $\mathrm{CV}$ of our analytical technique for both nutrients was normally less than $3 \%$, which indicates that the majority of the observed variation is a result of the sediment system. Despite this variation, changes in nutrient concentrations from one sampler were always reflected in its replicate. Data for samples collected at 20 to $40 \mathrm{~cm}$ for $\mathrm{NH}_{4}-\mathrm{N}$ and DRP showed similar trends, although concentrations were much lower than those at $10 \mathrm{~cm}$.

Representative $\mathrm{NH}_{4}-\mathrm{N}$ and DRP depth profiles occurring before, during and after the algal mat are illustrated in Fig. 2. These increases and decreases in $\mathrm{NH}_{4}-\mathrm{N}$ and DRP pore water concentrations corresponded to the occurrence and condition of the drift algae at the study site. The algal mat covered an area approximately $25 \times 200 \mathrm{~m}(\sim 5 \mathrm{~cm}$ thickness) and completely covered the grass sample site $(2 \times 4 \mathrm{~m})$ as well as the 'control' site. Concentrations of pore water nutrients rose as the algal mat closed around the sample site. Highest concentrations were noted when the decomposing mat had sunk and covered the grass. Once the algal mat was dissipated or had moved closer to shore, pore water concentrations returned to prealgal-mat values. A significant inverse correlation ( $\mathrm{r}=$ $-0.64,-0.90$ ) was found to exist between platinum electrode potentials and pore water DRP and $\mathrm{NH}_{4}-\mathrm{N}$ at $10 \mathrm{~cm}$, respectively. This inverse correlation indicates that as the sediment became more reduced, greater quantities of DRP and $\mathrm{NH}_{4}-\mathrm{N}$ were liberated to the pore water.
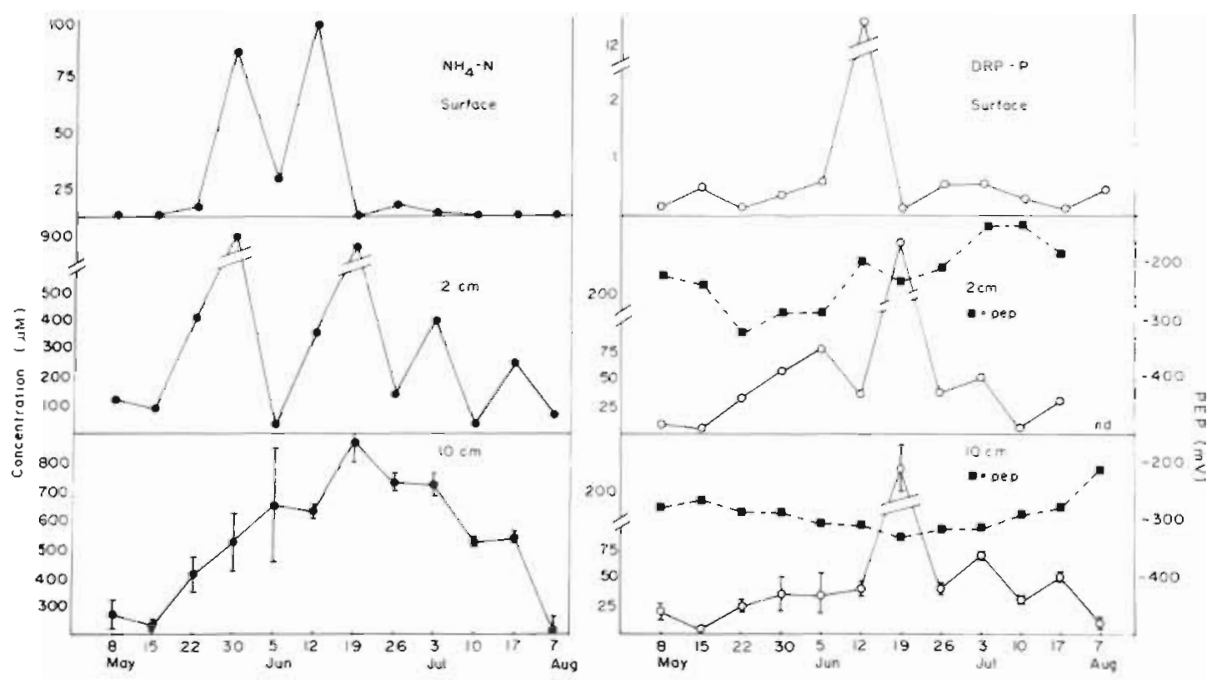

Fig. 1. Surface, 2 and $10 \mathrm{~cm}$ values ( \pm 1 standard deviation) for $\mathrm{NH}_{4}-\mathrm{N}, \quad \mathrm{DRP}$ and platinum electrode potential (PEP), 9 May to 7 Aug 1978 Only 1 sampler represented for $10 \mathrm{~cm}$ depth for 10 and 17 Jul 1978 
The same build-up of nutrients which occurred in the sediments of the grassbed also occurred at the 'control' site (Table 1). What is interesting is that $\mathrm{NH}_{4}-\mathrm{N}$ and DRP concentrations remained higher in the 'control' pore water than in the grassbed pore water after the algal mat had dissipated ( 7 Aug 1978). The fact that the control and grass site experienced the same buildup of nutrients during the algal mat's influence leads to the conclusion that even if the nutrient uptake mechanism of the seagrasses were shut down, it's influence was not a major factor contributing to this buildup.

However, the mechanism of seagrasses acting as a nutrient pump (McRoy and Barsdate, 1970) most probably was responsible for the more rapid return of nutrient concentrations prevalent in the pore water prior to the algal mat than in the control site which relied solely on diffusive and benthic flux rates. They reported a net overall transport of $\mathrm{P}$ from the roots of Zostera at $0.84 \mu \mathrm{g} \mathrm{P}$ plant $^{-1}$ day $^{-1}$. Assuming a $20 \mathrm{~cm}$ deep root zone and 5 plants in a $5 \mathrm{~cm}$ diameter area during a two week time period, a total of $90 \mu \mathrm{M} P$ would be taken up by the plant.

Surface values for ammonia and phosphate were also high during the sampling dates in June. Surface $\mathrm{NH}_{4}-\mathrm{N}$ concentrations of 5 June were lower than the week prior or after, but were still considerably higher than values determined in May, July or August. Ambient levels of $<5 \mu \mathrm{M} \mathrm{NH} \mathrm{NH}_{4}-\mathrm{N}$ and $<0.5 \mu \mathrm{M}$ DRP suddenly increased to $100 \mu \mathrm{M} \mathrm{NH}_{4}-\mathrm{N}$ and $13 \mu \mathrm{M}$ DRP. Surface oxygen values at times of collection were less than $5.0 \mathrm{ppm}$ and usually less than $2 \mathrm{ppm}$. Surface temperatures gradually increased from 27 to $29^{\circ} \mathrm{C}$ during the time period.

The decomposition of the algal mat may have increased concentrations of $\mathrm{NH}_{4}-\mathrm{N}$ and DRP in the mat such that the resulting concentration gradient precluded a flux from the sediment to the overlying water. We assume no drastic change in the rate of organic

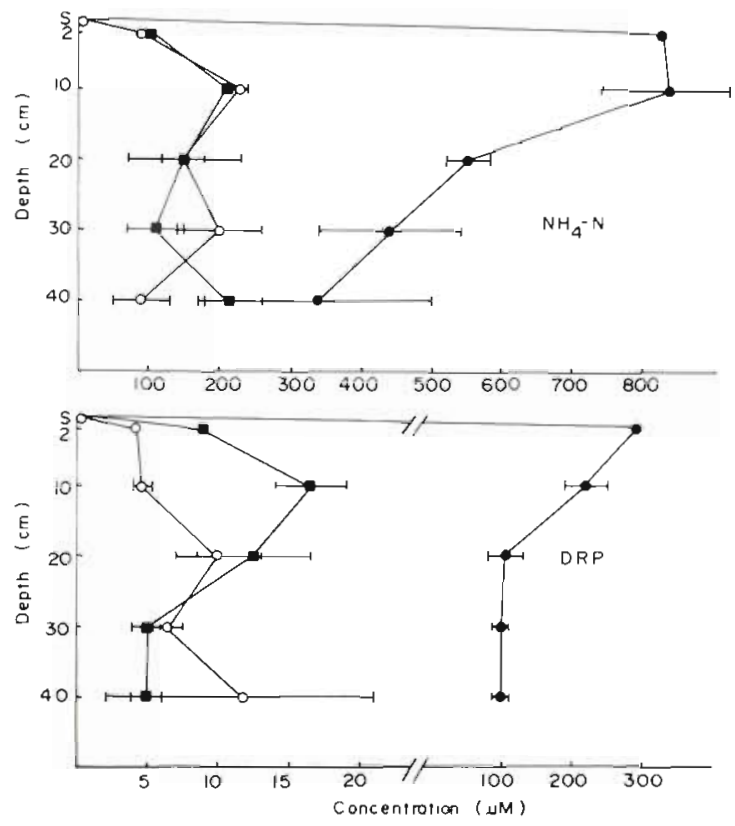

Fig. 2. Depth profiles of 3 representative data sets ( \pm 1 standard deviation). 015 May (pre algal mat); 19 Jun (height of algal mat decomposition); 7 Aug (post algal mat)

decomposition in the sediment for the following reasons. The rate of decomposition can be altered by changes in temperature (Abdollahi and Nedwell, 1979) and availability of substrate (Westrich and Berner, 1984). Higher temperatures $\left(30\right.$ to $32^{\circ} \mathrm{C}$ ) were noted at $10 \mathrm{~cm}$ from 12 to 26 June. This $5{ }^{\circ} \mathrm{C}$ difference in temperature normally found in the sediments during summer would increase the rate of diffusive flux by $12.5 \%$ and even if this temperature difference increased the decomposition rate by 10 to $20 \%$, it would not account for this large buildup of nutrients. Substrate availability should not change and export of fresh organic material into the sediment to a depth of $40 \mathrm{~cm}$ during a two week time period is highly unlikely. The concentration gradient may have been actually reversed, to cause a diffusive flux from the mat

Table 1. Comparison of pore water nutrient concentrations before, during and after drift-algal-mat settling on a Halodule wrightii seagrass bed and a control area devoid of seagrass

\begin{tabular}{|c|c|c|c|c|c|c|c|c|c|}
\hline \multirow[t]{3}{*}{ Date } & \multirow{3}{*}{$\begin{array}{l}\text { Depth } \\
\text { (cm) }\end{array}$} & \multicolumn{4}{|c|}{$\mathrm{NH}_{4}-\mathrm{N}(\mu \mathrm{M})$} & \multicolumn{4}{|c|}{$\mathrm{DRP}(\mu \mathrm{M})$} \\
\hline & & \multicolumn{2}{|c|}{ Control } & \multicolumn{2}{|c|}{ Grass } & \multicolumn{2}{|c|}{ Control } & \multicolumn{2}{|c|}{ Grass } \\
\hline & & $\overline{\mathrm{x}}$ & sd & $\overline{\mathrm{x}}$ & $s d$ & $\overline{\mathrm{x}}$ & sd & $\overline{\mathrm{x}}$ & sd \\
\hline \multirow[t]{3}{*}{15 May 1978 (pre algal mat) } & surface & 0.24 & 0.002 & 0.24 & 0.003 & 0.53 & 0.02 & 0.08 & 0.0 \\
\hline & $2 \mathrm{~cm}$ & 159.6 & 0.0 & 121.74 & 2.6 & 10.89 & 0.1 & 8.25 & 0.9 \\
\hline & $20 \mathrm{~cm}$ & 109.6 & 1.02 & 120.96 & 26.3 & 8.93 & 0.18 & 7.61 & 0.27 \\
\hline \multirow{3}{*}{$\begin{array}{l}19 \text { June } 1978 \\
\text { (algal mat decomposition) }\end{array}$} & surface & 0.50 & 0.00 & und. & - & und. & - & und. & - \\
\hline & $2 \mathrm{~cm}$ & 892.7 & 25.3 & 849.0 & 19.1 & 232.9 & 0.23 & 295.6 & 5.43 \\
\hline & $20 \mathrm{~cm}$ & 602.0 & 132.0 & 542.8 & 34.6 & 106.6 & 2.07 & 108.1 & 6.86 \\
\hline \multirow[t]{3}{*}{7 Aug 1978 (post algal mat) } & surface & 16.02 & 0.86 & 1.76 & 0.26 & 1.84 & 0.06 & 0.45 & 0.02 \\
\hline & $2 \mathrm{~cm}$ & 59.30 & 3.97 & 32.30 & 2.10 & 11.66 & 0.19 & 5.66 & 0.29 \\
\hline & $20 \mathrm{~cm}$ & 667.90 & 108.60 & 255.50 & 102.50 & 27.93 & 5.45 & 12.33 & 3.49 \\
\hline
\end{tabular}


to the sediment. Preliminary work on the decomposition rates of Microcoleus lyngbyaceus (F. Short, unpubl.) indicate a release of $3.8 \mu \mathrm{g} \mathrm{N} \mathrm{g}^{-1} \mathrm{dry}$ wt h $\mathrm{h}^{-1}$ in the early stages of decomposition which contributes substantially to the nitrogen availability to organisms in the surface waters.

A. comparison of the $\mathrm{NH}_{4}-\mathrm{N}$ ratios between the 2 and $10 \mathrm{~cm}$ depths demonstrated that the concentrations of $\mathrm{NH}_{4}-\mathrm{N}$ at $2 \mathrm{~cm}$ were less than at $10 \mathrm{~cm}$ on 8 and 15 May, 1978 and on 28 May was greater at $2 \mathrm{~cm}$. On 23 May and 19 June, the ratio of $\mathrm{NH}_{4}-\mathrm{N}$ between 2 and $10 \mathrm{~cm}$ was nearly $1: 1$. The sampling dates after 19 June indicated the $\mathrm{NH}_{4}-\mathrm{N}$ concentrations to be consistently higher at $10 \mathrm{~cm}$ than at $2 \mathrm{~cm}$.

The ratio of DRP between 2 and $10 \mathrm{~cm}$ was either $1: 1$ or greater $(>1: 1)$ from 16 May to 26 June, but then reversed $(\overline{\mathrm{x}}=1: 0.45)$ for the period 3 July to 7 August. These ratios demonstrate higher levels of DRP present at the $2 \mathrm{~cm}$ depth than at $10 \mathrm{~cm}$ during the time period when the algal mat was lying on top of the seagrasses, indicating a net flux movement into the sediment. As the algal mat began to dissipate, the ratio of DRP at $2 \mathrm{~cm}$ to DRP at $10 \mathrm{~cm}$ returned to $1: 1$ or greater.

Concentrations of $\mathrm{NH}_{4}-\mathrm{N}$ in the sediment pore waters increased at a faster rate than DRP, as indicated by the change in $\mathrm{N}: \mathrm{P}$ at 2 and $10 \mathrm{~cm}$ from ratios $>10: 1$ except on 19 June when the $\mathrm{N}: \mathrm{P}$ ratio dropped to $4: 1$.

We assumed the slope of the nutrient pore water concentrations between the sediment-water interface and $2 \mathrm{~cm}$ to be the same as the slope between 2 and $10 \mathrm{~cm}$. It would have been more accurate to use the slope from the sediment-water interface to $2 \mathrm{~cm}$ but precise sampling is virtually impossible in dense stands of seagrass due to the large mass of roots/ rhizomes and associated benthic organisms. This results in an underestimation of the diffusive flux.

These data lend support to the hypothesis that the decomposing algal mat reversed the nutrient concentration gradient in the sediment and was responsible for the subsequent buildup of dissolved nutrients in the sediment, resulting from continued decomposition. Once the algal mat dissipated, the concentration gradient was returned to normal.

Surface water samples were collected in the main channel of the intracoastal waterway (approximately $1.5 \mathrm{~km}$ from our sample site) on 30 May 1978. Dissolved ammonium concentrations were $5.2 \mu \mathrm{M}$ while surface values at our site were $80.0 \mu \mathrm{M}$. Dissolved phosphate concentrations were also elevated at the drift algal site. These differences in $\mathrm{NH}_{4}-\mathrm{N}$ concentrations indicate a very localized phenomenon as a result of the decomposing drift algal mat.

The data presented here demonstrate the ability of algal mats to influence nutrient dynamics in a local area. More detailed field and laboratory experiments are needed to ascertain the rates of nutrient uptake and release by blue-green algae and seagrass mats.

Acknowledgements. The authors thank M. Price and S. Blair for field assistance and identification of algae. Dr. J. Ryther, $M$. Davis, R. Gibson and an anonymous reviewer critically reviewed the manuscript and their comments are appreciated. We gratefully acknowledge the financial support provided by Harbor Branch Foundation, Inc. This is Harbor Branch Foundation, Inc., contribution number 388.

\section{LITERATURE CITED}

Abdollahi, H., Nedwell, D. B. (1979). Seasonal temperature as a factor influencing bacterial sulfate reduction in a saltmarsh sediment. Microb. Ecol. 5: 73-79

Aller, R. C. (1978). Experimental studies of changes produced by deposit feeders on pore water, sediment and overlying water chemistry. Am. J. Sci. 278: 1185-1234

Aller, R. C., Yingst, J. Y. (1978). Biogeochemistry of tube dwellings: a study of the sedentary polychaete Amphitrite omata (Leidy). J. mar. Res. 36: 201-254

Berner, R. A. (1974). Kinetic models for the early diagensis of nitrogen, sulfur, phosphorus, and silicon in anoxic marine sediments. In: Goldberg, E. D. (ed.) The sea, Vol. 5. Wiley, London, p. $427-450$

Benz, M. C., Eiseman, N. J. and Gallaher, E. E. (1979). Seasonal occurrence and variation in standing crop of a drift algal community in the Indian River, Florida. Botanica mar. 22: 413-420

DeJong, V. N., Villerius, L. A. (1980). Interference of sulfide in inorganic phosphate determination in natural waters. Mar. Chem. 9: 191-197

McRoy, C. P., Barsdate, R. J. (1970). Phosphate absorption in eelgrass. Limnol Oceanogr. 15: 6-13

McRoy, C. P., Barsdate, R. J., Nebert, M. (1972). Phosphorus cycling in an eelgrass (Zostera marina L.) ecosystem. Limnol. Oceanogr. 17: 58-67

Montgomery, J. R., Zimmermann, C. F., Price, M. T. (1979). The collection, analysis and variation of nutrients in estuarine pore waters. Estuar. coast. mar. Sci. 9: 203-214

Montgomery, J. R., Zimmermann, C., Peterson, G., Price, M. (1983). Diel variations of dissolved ammonia and phosphate in estuarine sediment pore water. Fla Scient. 45: 535-542

Rosenfeld, J. K. (1979). Ammonium adsorption in nearshore anoxic sediments. Limnol. Oceanogr. 24: 354-364

Short, F. T (1983). The response of interstitial ammonium in eelgrass (Zostera marina L.) beds to environmental perturbations. J. exp. mar. Biol. Ecol. 68: 195-208

Westrich, J. T., Berner, R. A. (1984). The role of sedimentary organic matter in bacterial sulfate reduction: the $\mathrm{G}$ model tested. Limnol. Oceanogr. 29: 236-249

Zimmermann, C., Price, M., Montgomery, J. (1977). Operation, methods and quality control of Technicon AutoAnalyzer II systems for nutrient determinations in seawater. Harbor Branch Foundation, Inc. Technical Report 11

Zimmermann, C., Price, M., Montgomery, J. (1978). A. comparision of ceramic and teflon in situ samplers for nutrient pore water determinations. Estuar. coast. Mar. Sci. 7: 93-97

Accepted for printing on July 14, 1984 